\title{
O que resta do segredo
}

\section{Elisa de Magalhães ${ }^{1}$}

Resumo: Este artigo vai abordar o segredo, ou o que resta dele, a partir de Jacques Derrida, sobretudo nos livros Demorar e Paixões, da psicanálise de MD Magno, a Teoria do Revirão, e do filme Amor à flor da pele de Wong Kar-Wai. O texto aborda a impossibilidade do testemunho, o segredo como aberto e permanentemente inalcançável, como o movimento da différance.

Palavras-chave: segredo, testemunho, différance, paixão

\section{What's left of the secret}

\begin{abstract}
This article will address the secret, or what remains of it, from Jacques Derrida, especially in the books Demeure: fiction and testimony and Paissions: an oblique offering, from the psychoanalysis of MD Magno, the Theory of Revirão, and from the film In the mood for love by Wong Kar -Wai. The text addresses the impossibility of testimony, the secret as open and permanently unreachable, like the différance movement.
\end{abstract}

Keywords: secret, testimony, différance, passion

1 Elisa de Magalhães é artista, com exposições individuais e coletivas no Brasil e no exterior. Professora da EBA/UFRJ e do PPGAV/UFRJ, Pós-Doutora em Filosofia pelo PPGF/UFRJ, Pós-Doutora em Artes pelo PPGCA/UFF, Doutora em Artes Visuais pelo PPGAV/UFRJ, Mestre em Artes pelo PPGARTES/UERJ, graduada em Comunicação Social pelo ECO/ UFRJ. Publicou o livro Nenhuma Ilha, sobre parte de sua trajetória artística, em 2014, com organização de Marcelo Campos. Vínculo institucional: Universidade Federal do Rio de Janeiro, UFRJ, Av. Pedro Calmon, Rio de Janeiro, 21941901. E-mail: edemagalhaes@gmail.com. ORCID: https://orcid.org/0000-0002-6317-2227. Lattes iD: http://lattes. cnpq.br/3634320208508286. Rio de Janeiro, Brasil. Nome do autor para citação: Magalhães, E. DE. 
Neste texto quero abordar o segredo, ou escrever sob a égide do segredo, partindo da pergunta o que resta do segredo?

O aqui o dito não é segredo e nem é somente sobre o segredo. Aqui, fala-se de paixão, testemunho e arquivo. Vai-se friccionar o tempo todo a fronteira entre verdade e ficção, ou entre verdade e mentira, ou, ainda, entre verdade e invenção. Mais: considera-se, aqui, o segredo como uma impossibilidade ou como uma improbabilidade. Todavia, ele há, mesmo que entre o haver e o não-haver, como diria o psicanalista brasileiro MD Magno. Pensando nesse indecidível, há lugar do segredo? Há realmente algo secreto no segredo? O que resta de segredo nos arquivos?

Faço aqui um parênteses para falar da Teoria do Revirão, de Magno. O psicanalista divide a psique humana entre o haver e o não-haver. Ele a imagina como uma fita de Moebius, mas dobrada, a imagem é de uma asa de borboleta. O Haver corresponderia àquilo que nos cerca, aquilo que podemos ver, e ao que pertencemos. O Não-Haver corresponderia ao inconsciente, ou ao real inalcançável. Tomo emprestado os termos de Magno com a liberdade de deslocá-los ligeiramente do sentido original. Diferentemente da psique humana, é como se pudéssemos estar, ao mesmo tempo, no Haver e no Não-Haver, como se o segredo tivesse o dom da ubiquidade e tivesse, ao mesmo tempo, um pé em cada lugar.

Derrida lembra no texto A Escritura e a Diferença, que Freud escolhe representar o aparelho psíquico como uma máquina de escrita: um brinquedo de criança, o bloco mágico. A metáfora apresenta o inconsciente como o bloco de cera, onde restam os rastros da escrita sobre o papel que o cobre. A brincadeira é levantar o papel e a escrita desaparece dali, de modo que se pode preencher mais uma vez a superfície inscritível. Derrida lembra que - e falo sempre a partir da leitura que ele faz de Freud - a formação da memória se forma na exploração e escolha de caminhos entre os traços deixados no bloco de cera. Ou melhor, "o traço como memória não é uma exploração pura que sempre se poderia recuperar como presença simples, é a diferença indiscernível e invisível entre as explorações." A memória se dá pela diferença. O segredo talvez esteja naquilo que foi desprezado em exploração e escolha de caminhos e jamais retorna como memória. O segredo é da ordem do trauma e só retorna como sintoma.

Tomo como alegoria para este texto o filme Amor à flor da pele, de Wong Kar Wai, no qual os personagens Chow Mo-wan e Su Li-zhen, inicialmente amigos e vizinhos, por conta do afastamento profissional de seus companheiros, vão se apaixonando. Ao mesmo tempo, seus companheiros 
tornam-se amantes e ambos descobrem o segredo deles. E seguem numa atmosfera sufocante de desejo reprimido, os dois se consolando mutuamente da traição de seus parceiros, mas não cedem ao próprio desejo. E levam esse segredo - da vontade do sexo e da repressão ao desejo - para o resto de suas vidas. Na cena final do filme, e isto é um spoiler, Chow Mo-wan vai até as ruínas do templo de Angkor Vat, no Camboja, para lá depositar seu segredo. Falar para a pedra, fiel depositária do secreto e única testemunha.

Chow Mo-wan diz para a pedra aquilo que é o clandestino, confessa o que é inconfessável, dá, ali, o testemunho impossível. Ele sente o dever de confessar, de cometer o perjúrio, mas não tem o direito de fazê-lo, e resolve o conflito entre direito e dever, depositando o indizível naquilo que nada pode dizer, no lugar do segredo.

Trago Paul Célan como uma outra alegoria possível, citado em livro sobre hermetismo e hermenêutica na sua obra, organizado por Flávio Kothe:

\author{
De antemão obscurecida, ainda uma vez, \\ se achega a tua fala \\ até a folha-motriz sempre em sombras \\ da faia.
}

Não há

nada que se possa fazer convosco,

é teu fardo a servidão de uma estranheza.

Infindamente

ouço a pedra estar em ti. ${ }^{1}$

1 Kothe, Flávio R. (org.). Hermetismo e hermenêutica: Paul Celan - Poemas II. Tradução Flavio R. Kothe. Rio de Janeiro: Tempo Brasileiro, São Paulo: Instituto Hans Staden, 1985, p. 189. 
A pedra como o único possível ou provável lugar do inconfessável, algo que estará ali, ainda depois.

Em Donner la mort, Jacques Derrida fala da relação entre responsabilidade, silêncio e o segredo do secreto, a partir de uma reflexão de Kierkegaard. No livro ele lembra que no Antigo Testamento, Deus diz para Abrahão matar seu primogênito, Isaac, como prova de fé. E pede que ele guarde segredo sobre isso, ninguém pode saber, nem seus filhos, nem sua muIher. Guardar esse segredo terrível, de dar a morte a seu filho, à garantia de seu futuro, era guardar o segredo absoluto, que o destacava de toda a sociedade perante Deus. Assim, num só ato, Deus pede a Abrahão, o patriarca obrigado ao bem-estar dos seus, não somente a responsabilidade do silêncio, mas a traição. Guardar segredo é mentir - Sarah, sua esposa, percebia que Abrahão não estava agindo normalmente, perguntava o que havia, para onde ele ia e Abrahão sempre mentia -, assim como confessar é cometer perjúrio. O assassinato de Isaac só não é consumado porque, no gesto da execução, um anjo troca seu corpo por um cordeiro. Por obediência Abraão é capaz de mentir e trair. Por amor a Deus, Abraão pede desculpas por obedecê-lo. É sobre o perjúrio, a traição e o assassinato que se fundam as 3 grandes religiões monoteístas, e assim se funda o ocidente.

Em Demorar - Maurice Blanchot, Derrida diz que o testemunho está sempre relacionado à ficção e à mentira. A testemunha é aquela que guarda um segredo, que lhe foi transmitido de cor - expressão que vem do latim, cor, coração, isto é, aquilo que te afeta é mantido em seu íntimo. Sua confissão, da mesma maneira, será de memória. Mesmo engajado em dizer a verdade, nada que o testemunhante diga se poderá provar. Acreditar no testemunho é um ato de fé. O testemunhante apela ao outro porque "...não há testemunho que não implique estruturalmente em si mesmo a possibilidade de ficção, de simulacro, de dissimulação, de mentira e de perjúrio..."2. Porque se o testemunho torna-se prova, certeza ou arquivo, ele perde sua função de testemunho e torna-se outra coisa: prova, certeza, etc. Para ser testemunho, ele deve estar nesse limite impossível, insustentável, indecidível. É ele, o limite, que devota o testemunho ao segredo, que determina que ele permaneça secreto lá mesmo onde fica manifesto e público. Antes de ser testemunho, a confissão é segredo reservado a quem o guarda. Justamente por isso, a condição do testemunho ou da confissão é permanecer segredo; 
no entanto, o testemunhante tem o dever de dizê-lo. E embora pareça contraditório, a experiência do segredo implica sempre em algum testemunho, para si ou para algum terceiro que toma para si o testemunhar. Se o testemunho é limite, estamos numa espécie de topologia, daí a questão do lugar na nossa reflexão ser recorrente - e a topologia que nos assombra nesse caso parece ser a da fita de Moebius, cuja característica é que se pode andar sobre ela, em toda sua extensão, no fora e no dentro, sem precisar atravessar nada, porque não há divisão. Sendo assim, a testemunha, ela participa do segredo ou ela é o terceiro? Qual o lugar da testemunha? Mas há também uma temporalidade própria do testemunho: o momento da confissão é o da revelação de um instante, porque o segredo tem a instância do instante - ele é singular. A revelação ou repetição do segredo torna-o universalizável. O testemunho destrói a característica indivisível do instante, mas é essa destruição que torna possível o testemunho.

Faço aqui uma analogia com o horizonte de eventos, uma fronteira de topologia indeterminável, que é a beirada dos buracos negros. Pode-se estar aí, mas não se pode demorar, sob risco de ser absorvido pelo buraco negro e tornar-se a mesma matéria dele: singularidade. Estar no horizonte de eventos é estar aí e não estar, ao mesmo tempo, tem a instância do instante, a iminência da revelação.

Percebemos com isso que o testemunho tem um caráter performativo, porque é um ato presente e o testemunhante é insubstituível: somente aquele que guarda o segredo pode dizer sobre ele. E para que o segredo seja revelado ou para que o testemunho possa acontecer, é preciso que haja um acordo da língua, ou não se poderá compreendê-lo. O testemunho só é garantido se sua tradutibilidade estiver prometida.

Toda essa performatividade do segredo e do testemunho é mediada pelo corpo. E, porque toda revelação - revelar é velar duas vezes - é ficção ou mentira, resta um secreto do segredo no corpo testemunhante. O secreto, o inconfessável, aquilo que resta irremediavelmente encriptado é carregado pelo corpo, inatingível, intransmissível, incomunicável. E deve permanecer intacto.

Voltemos à história do filme, Amor à flor da pele. Chow Mo-wan resolve o conflito, transmitindo o incomunicável, o intransmissível para a pedra, performativamente. Nessa cena, a câmera passeia por sobre as ruínas de Angkor-Vat até achar, primeiramente a figura de um menino-monge, que está sentado em uma janela e que observa o personagem que chega, procura um lugar e lá deposita seu segredo. Não se ouve o que ele fala, ou 
sussurra, para uma fenda nas ruínas do templo cambojano, mas seu corpo revela o incomunicável; o segredo está lá: ele não se apresenta, e o que resta dele é traço ou o movimento do traço que não deixa traço. Isto é, se não há o que testemunhar, porque inatingível, intransmissível, incomunicável, mas ainda assim há, é preciso dar o testemunho disso, como fez Chow Mo-wan: há que se estar na experiência do traçamento do traço que não deixa traço, performativamente, há que se experimentar o lugar do secreto. Mas qual é o lugar do segredo? Onde ele começa e onde termina?

Penso que o lugar do segredo está naquele/naquilo que o acolhe, porque, para estar aberto ao segredo, é preciso paixão, é experimentar o conflito entre o sacrifício e a transcendência. Não há paixão sem segredo, mas não há segredo sem paixão - ele, o segredo, sabemos sempre de cor. Na relação do corpo performativo com o outro, há a produção de uma alteridade, de um suplemento, radical, absoluto que assombra o corpo que performa. O ato de perjúrio está não na apresentação ou narrativa do segredo, mas na performatividade do corpo que testemunha. Somente fora do logos é possível dizer o indizível: o secreto é estranho à palavra. O testemunho chega obliquamente, revelando e velando o segredo, num jogo de intermitência entre o vigiar e o pôr o véu.

O corpo denuncia, os corpos de Chow Mo-wan e Su Li-zhen anunciam: há segredo aí, que não diz mais respeito ao privado que ao público, e que deve ser revelado - é preciso que se preste conta desse segredo - porque ele permanecerá inviolável, mesmo que revelado. "Não há / nada que se possa fazer convosco, / é teu fardo a servidão de uma estranheza. / Infindamente / ouço a pedra estar em ti."

Os corpos de Chow Mo-wan e Su Li-zhen denunciam: há segredo aí, com conteúdo inseparável de sua experiência e de seu enunciado performativos.

Os corpos de Chow Mo-wan e Su Li-zhen denunciam: há paixão aí, porque há desejo de confissão, porque há desejo de uma certa passividade à lei do outro, porque há uma dívida do ser-diante-da-lei, porque se assume o engajamento no sofrimento ou no padecer. O testemunho é paixão, por estar ligado à mentira, à ficção e ao perjúrio. Paixão, lembra Derrida em Demorar, pode ser um outro nome para différance - "uma différance que se deixa escrever na gramática de uma determinada voz mediana, e mesmo se ela não se confina a uma tal gramática histórica, différance poderia 
se reduzir a um outro nome para paixão" 3 -, porque, mesmo que se revele o segredo no que se dá a ver, ou no que se apresenta no testemunho, há aquilo que sempre escapa. Há sempre uma camada ficcional, mentirosa, inventada, inatingível, porque quem conta tem o privilégio do segredo. Talvez, o que reste dele seja a possibilidade ou a probabilidade de demorar no inalcançável, lá onde jamais teremos acesso. Um lugar sem lugar, porque escapa até mesmo como topologia. Nas palavras de Derrida: "Eis o que resta, a solidão absoluta de uma paixão sem martírio." ${ }^{4} \mathrm{Ou}$, resta o trauma, que ressurge como sintoma ou no retorno do recalcado.

Para encerrar, trago Rainer Maria Rilke, com a tradução de Augusto de Campos do poema L'Ange du méridien:

Pétreo, como saber das nossas penas?

Acaso teu sorriso é mais risonho

À noite, quando expõe a pedra em sonho? ${ }^{5}$

3 Derrida, Jacques. Demorar - Maurice Blanchot. Tradução Flávia Trocoli e Carla Rodrigues. Florianópolis: Editora UFSC, 2015, p. 36.

4 Derrida, Jacques. Paixões. Tradução Lóris Z. Machado. Campinas: Papirus, 1995, p. 51.

5 Campos, Augusto de. Coisa e anjos de Rilke. São Paulo: Perspectiva, 2001, p. 47. 


\section{Referências bibliográficas}

CAMPOS, Augusto de. Coisas e anjos de Rilke / Augusto de Campos. São Paulo: Perspectiva, 2001.

DERRIDA, Jacques. Demorar - Maurice Blanchot. Tradução Flávia Trocoli e Carla Rodrigues. Florianópolis: Editora UFSC, 2015.

. Donner la mort. Paris: Éditions Galilée, 1999.

. Paixões. Tradução Lóris Z. Machado. Campinas: Papirus, 1995.

KOTHE, Flávio R. (org.). Hermetismo e hermenêutica: Paul Celan - Poemas

II. Tradução Flavio R. Kothe. Rio de Janeiro: Tempo Brasileiro, São Paulo: Instituto Hans Staden, 1985.

MAGNO, MD. Revirão 200/2001: arte da fuga / clínica da razão prática. Rio de Janeiro: Novamente, 2003.

\section{Referências filmográficas}

KAR-WAI, Wong. Amor à flor da pele. DVD Vídeo, Novo Disc Mídia Digital da Amazônia, 97 min. 